\title{
Zinc and COVID-19: Basis of Current Clinical Trials
}

\author{
Amit Pal ${ }^{1}$ (1) - Rosanna Squitti ${ }^{2} \cdot$ Mario Picozza $^{3} \cdot$ Anil Pawar $^{4} \cdot$ Mauro Rongioletti $^{5} \cdot$ Atanu Kumar Dutta $^{1}$. \\ Sibasish Sahoo ${ }^{1} \cdot$ Kalyan Goswami $^{1} \cdot$ Praveen Sharma $^{6} \cdot$ Rajendra Prasad $^{7}$
}

Received: 13 August 2020 / Accepted: 11 October 2020 / Published online: 22 October 2020

(C) Springer Science+Business Media, LLC, part of Springer Nature 2020

\begin{abstract}
Coronavirus disease-2019 (COVID-19) pandemic continues to threaten patients, societies, and economic and healthcare systems around the world. Like many other diseases, the host immune system determines the progress of COVID-19 and fatality. Modulation of inflammatory response and cytokine production using immunonutrition is a novel concept that has been applied to other diseases as well. Zinc, one of the anti-inflammatory and antioxidant micronutrient found in food with well-established role in immunity, is currently being used in some clinical trials against COVID-19. This review integrates the contemporary studies of role of zinc in antiviral immunity along with discussing its potential role against COVID-19, and ongoing COVID-19 clinical trials using zinc.
\end{abstract}

Keywords COVID-19 $\cdot$ Clinical trials $\cdot$ Immunity $\cdot$ Zinc

\section{Introduction}

As the whole world is grappling with coronavirus disease2019 (COVID-19) pandemic caused by the severe acute respiratory syndrome coronavirus-2 (SARS-CoV-2), there is a frantic race for finding treatment regimens based on current knowledge until effective vaccine and ad hoc drugs are developed. Indeed, therapeutic approaches against COVID-19, mostly centered on the management of its immunopathology and/or tailored to directly control viral replication, are for now based on off-label prescription. Several human trials are currently in

Amit Pal

maximus1134@gmail.com; amit.biochem@aiimskalyani.edu.in

1 Department of Biochemistry, All India Institute of Medical Sciences (AIIMS), Kalyani, West Bengal 741245, India

2 Molecular Markers Laboratory, IRCCS Istituto Centro San Giovanni di Dio Fatebenefratelli, Brescia, Italy

3 Neuroimmunology Unit, IRCSS Fondazione Santa Lucia, 00143 Rome, Italy

4 Department of Zoology, DAV University, Jalandhar, Punjab, India

5 Department of Laboratory Medicine, Research and Development Division, San Giovanni Calibita Fatebenefratelli Hospital, Isola Tiberina, Rome, Italy

6 Department of Biochemistry, AIIMS, Jodhpur, Rajasthan, India

7 Department of Biochemistry, MM Institute of Medical Sciences and Research, Mullana, Ambala 133207, Haryana, India progress to assess the therapeutic indexes of drugs already approved for other diseases (i.e., drug repurposing), and in combination with dietary supplements like vitamin $\mathrm{C}$, vitamin $\mathrm{D}$, vitamin $\mathrm{B}_{12}$, probiotics, and zinc ( $\left.\mathrm{Zn}\right)$. $\mathrm{Zn}$ is a common theme in both prophylactic and curative COVID-19 clinical studies using nutritional supplements.

$\mathrm{Zn}$, the second most abundant trace metal in the human body after iron, is essential for multiple cellular functions including maintenance of immune health. Notably, "Zn proteome" is estimated to encompass around 3000 proteins [1] including $\sim 750 \mathrm{Zn}$ finger transcription factors, a number of which are deeply implicated in homeostasis and inflammation. Ever since $\mathrm{Zn}$ deficiency was demonstrated as a human disease more than 56 years ago, it has been implicated in immune dysfunction, growth retardation, hypogonadism, and cognitive impairment $[2,3]$. Importantly, $\mathrm{Zn}$ also plays a critical role in antiviral immunity $[4,5]$. Readers are referred to specialized reviews on essential role of $\mathrm{Zn}$ in human health (including $\mathrm{Zn}$ homeostasis and transporters) and other non$\mathrm{viral} /$ viral diseases [5-16].

With so many clinical trials going on against the COVID19 pandemic, there is scientific curiosity about the nature and basis of these trials [17]. In this review, we will discuss the basis of clinical trials using adjunct $\mathrm{Zn}$ therapy for COVID-19 through the prism of its indispensable role in antiviral immunity along with briefly discussing immunopathology of COVID-19. 


\section{COVID-19 Immunopathology}

As already shown for SARS and Middle East respiratory syndrome (MERS), the host immune response plays a central role also in the pathology associated to SARS-CoV-2 infection, as the fatalities occurring among COVID-19 patients are often preceded by the so-called cytokine storm, a massive systemic release of proinflammatory cytokines such as interleukin (IL)$1 \mathrm{~b}$, IL-6, and tumor necrosis factor- $\alpha$ (TNF- $\alpha$ ). These events ultimately contribute to acute respiratory distress syndrome (ARDS) and lead to vascular hyperpermeability, diffuse coagulopathy, multi-organ failure, and eventually death $[18,19]$. These cytokines are mainly secreted by innate immune cells such as monocytes, macrophages, and dendritic cells (DC), which are supposed to act mainly in the early phases of infections. However, cytokine storm occurs at late stages of SARS$\mathrm{CoV}-2$ infection, when the adaptive, instead of the innate immune response, is known to become prominent.

A series of timely coordinated actions are required for an effective immune response against viral infections, and the agenda in which these actions move may be outlined by opposing early/innate versus late/adaptive immune response waves. Firstly, innate immune and infected tissue cells initiate primitive and unspecific reactions in an attempt to restrain viral replication by producing type-I interferons (IFN), IFN- $\alpha$ and IFN- $\beta$, and to attract blood cells to the site of infection by producing chemokine and TNF- $\alpha$, which activates endothelial cells enhancing vascular adhesion and diapedesis of leukocytes, and by secreting other proinflammatory cytokines to activate leukocytes. It is peculiar that, while SARS-CoV-2 replication in permissive cells may be effectively inhibited by exogenously added type-I IFN, endogenous production of IFN- $\alpha$ and IFN- $\beta$ upon infection is inhibited by proteins encoded by SARS-CoV-related viruses, whereas chemokines and inflammatory cytokines are highly produced contributing to an unbalanced response [20,21].

During this first phase of the immune response, DC migrate to lymph nodes and initiate a complex and slower intercellular cascade, ultimately culminating in the expansion and maturation of adaptive, virus-specific $\mathrm{T}$ and $\mathrm{B}$ lymphocytes. Seroconversion-i.e., the appearance in the blood of antibodies against immunogenic viral proteins - and probably the clonal expansion of virus-specific $\mathrm{T}$ cells, occurs in most COVID-19 patients 10 days after symptom onset [22] and severe disease and cytokine storm are associated in time and magnitude with the immunoglobulin response in SARS-CoV$1[23]$ and SARS-CoV-2 infection [24, 25].

Strikingly, a similar cytokine storm is also the most notable side effect of chimeric antigen receptor $\mathrm{T}$ (CAR-T) cell therapy, and its severity is forecasted by the extent of tumor burden [26], leading to the hypothesis that a high antigen (i.e., viral) load at the time of the (late) adaptive immune cell activity against SARS-CoV-2, when antibodies and virus-specific
$\mathrm{T}$ cells arise, may favor a massive second wave of cytokine release by innate cells in a positive feedback loop. Much effort is now trying to decipher, in the immunotherapy setting, the exact mechanisms pushing this positive feedback from adaptive to innate cells, which may deserve our attention to anticipate plausible pathways to interfere with COVID-19 immunopathology. One line of evidence points to cytokines produced by $\mathrm{T}$ cells upon antigenic stimulation, namely to TNF- $\alpha$ [27] and granulocyte-macrophage colony-stimulating factor (GM-CSF) [28], as triggers of the secondary systemic toxic cytokine release by innate cells. Importantly, these two cytokines are unnecessary (both) or detrimental (GM-CSF) for on-target effects of CAR-T cells [28], which suggests that they may be dispensable also for the antiviral response to SARS-CoV-2.

There is a clear sex- and age-dependent bias in COVID-19related mortality. Better outcomes in women, for instance, may be the result of a more pronounced IFN- $\alpha$ production by plasmacytoid DC [29] during initial phases of infection. The more effective viral containment operated by such a response could be assumed to lower the antigen load at the onset of the adaptive wave and prevent the cytokine storm. In studies from patients during the 2003 SARS-CoV-1 outbreak, treatment with synthetic type-I IFN in conjunction with steroids has proven useful to ameliorate pneumonia course [30], and early, in contrast to delayed, type-I IFN treatment rescued mice from death after SARS-CoV-1 infection [31]. On the other hand, aging of the immune system, which is associated to chronic low-level activation of innate cells, also entails a delayed and inflated response upon pathogen encountering [32]. Lastly, with age, adaptive cells become slow in mounting antigen-specific responses to novel pathogens secondary to the loss of the naive $\mathrm{B}$ and $\mathrm{T}$ cell repertoire due to thymic involution [33].

\section{Immunological Functions of $\mathbf{Z n}$}

Data gleaned from seminal animal model studies have added considerable knowledge about the principal roles of $\mathrm{Zn}$ in the immune system. $\mathrm{Zn}$ is an essential micronutrient, which plays an important role in the physiology of the immune system by acting as signaling molecule. Zn not only acts as an antiinflammatory agent but also functions as an antioxidant stabilizing membrane [34]. Zn deficiency impinges on survival of immune cells and adversely affects important functions such as phagocytosis, target cell killing, and cytokine production (Fig. 1). It is clearly evident from studies on preclinical models that $\mathrm{Zn}$ deficiency plays a role in thymus and lymphoid tissue atrophy [35] and declines in the mechanisms of activation of both helper $\mathrm{T}$ cell [36] and cytotoxic $\mathrm{CD} 8^{+} \mathrm{T}$ cell responses [37]. Specifically, Zn deficiency leads to compromised immune system, as evidenced by degeneration of thymus, 
Fig. 1 Balance between helpful and harmful effects of zinc for COVID-19

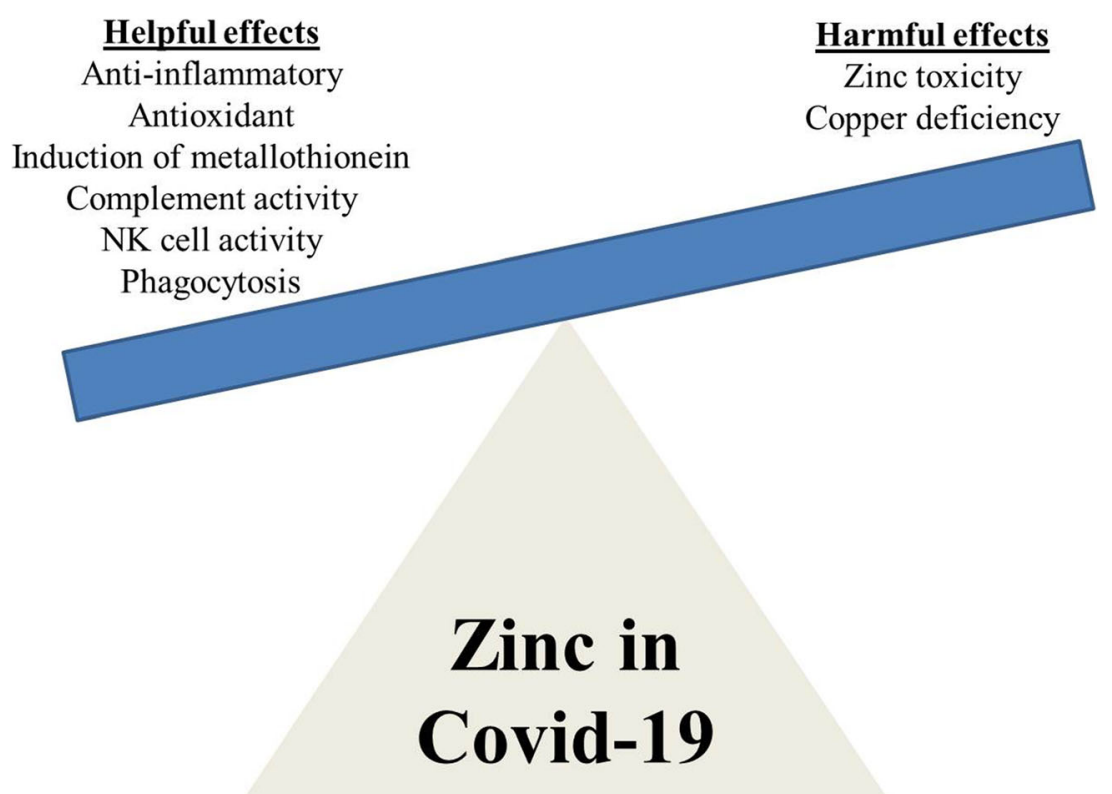

Helpful effects

Anti-inflammatory

Zinc toxicity

Copper deficiency lymphopenia, and defective lymphocyte responses [3, 5, 34]. Zn deficiency causes immunodeficiency with severe lymphopenia that is characterized in part by a considerable decrease in developing B cell compartments in the bone marrow $[3,38]$. Moreover, $\mathrm{Zn}$ potentiates IFN- $\alpha$ effect by an order of magnitude [39] which can be used to counteract IFN antagonism by SARS-CoV-2 proteins.

A marked neutrophilia is observed in severe COVID-19 patients [40]. $\mathrm{Zn}$ gluconate supplementation is able to reduce airway neutrophil infiltration and TNF- $\alpha$ release by inhibiting NF$\mathrm{kB}$-dependent transcription of inflammatory genes [41]. The $\mathrm{Zn}$ finger CCHC-type containing 3 (ZCCHC3) potentiates TLR3 signaling induced by double-strand RNA [42], which is produced during intracellular replication of coronaviruses.

In vitro, $\mathrm{Zn}$ deficiency induced enhanced IL- 6 and IL- $1 \beta$ production, as well as higher expression of intercellular adhesion molecule 1 (ICAM-1), important for leukocytes' extravasation, of CD86, a co-stimulatory molecule involved in T cell activation, and of HLA-DR, a MHC-II molecule, in cultured human monocytic cells [43]. Moreover, aged mice have lower plasma $\mathrm{Zn}$ concentration, and this was associated to higher IL-6 and ICAM-1 gene expression in splenocytes [43]. Thus, $\mathrm{Zn}$ supplementation may be instrumental to reduce inflammatory cytokines, particularly IL-6 and IL$1 \beta$, and at the same time to enhance the protective, though inhibited, type-I IFN response in SARS-CoV-2 infection. Zn deficiency indicates towards the decreased interferon- $\gamma$ (IFN- $\gamma$ ) production, a major component of Th1 cytokine panel [44]. Since Th1 and Th2 responses are mutually inhibited by the effect of their respective signature cytokines IFN- $\gamma$ and IL-4, such imbalance between Th1 and Th2 might lead to dysfunctions in cellmediated immune response [34].
There can be a whole lot of factors for the development of Zn deficiency, whether geographic, socioeconomic, nutrition$\mathrm{al}$, or as a result of disease pathologies such as chronic viral infections. Notably, during infection, Zn levels decrease significantly and a person's requirement for $\mathrm{Zn}$ may increase with the severity of the infection. Aged individuals, infants, and chronic alcoholics are particularly more susceptible to $\mathrm{Zn}$ deficiency, increasing their chances of acquiring lifethreatening viral infections [45-48]. As $\mathrm{Zn}$ is indispensable for a strong immune response, $\mathrm{Zn}$ deficiency (persistent hypozincemia [serum $\mathrm{Zn}<70 \mu \mathrm{g} / \mathrm{dL}$ ]) can considerably dampen innate as well as adaptive antiviral immunity $[4,5]$.

\section{The Role of $\mathrm{Zn}$ in Antiviral Immunity}

There is very scant information available on the role and effect of $\mathrm{Zn}$ in SARS and coronavirus disease, even though literature is rapidly increasing [17, 49]. Much of the current knowledge about the use of $\mathrm{Zn}$ as an antiviral therapy and immunomodulatory agent has originated from studies done with other viral diseases (Readers are referred to these specialized articles for role of $\mathrm{Zn}$ in viral diseases $[4,5])$. $\mathrm{Zn}$ is an essential constituent of thymulin hormone, which is involved in maturation and differentiation of $\mathrm{T}$ cells in thymus gland. $\mathrm{Zn}$ not only plays an important role in IL- 2 and IFN- $\gamma$ production but also stimulates macrophages to produce IL-12. IL-12 activates the natural killer cells and T cytotoxic cells. Both IFN- $\gamma$ and IL12 play a crucial role in destruction of various pathogens. Among anti-inflammatory cytokines, only IL-10 production is affected by $\mathrm{Zn}$ deficiency, whose enhanced levels adversely affect the functioning of macrophages and Th1 response [50]. 
The rationale behind the use of $\mathrm{Zn}$ in COVID-19 studies aroused from the observation that $\mathrm{Zn}$ ions and $\mathrm{Zn}$ ionophores, such as pyrithione (PT), have previously been described as potent inhibitors of various RNA viruses [51]. Also, targeting of RNA-dependent RNA polymerase (RdRps) of RNA viruses like SARS-CoV-2 is more suitable for antiviral drug development as RdRp activity is strictly virus-specific and may be blocked without severely affecting key cellular functions. The basis of $\mathrm{Zn}$ therapy in coronavirus infection is shown in Fig. 2. It is known previously that $\mathrm{Zn}$ ions are involved in many different cellular processes, proper folding, and activity of various cellular enzymes and transcription factors. On the other hand, $\mathrm{Zn}^{2+}$ is probably an important cofactor for numerous viral proteins as well. $\mathrm{Zn}^{2+}$ can serve as intracellular second messenger and may trigger apoptosis or a decrease in protein synthesis at elevated concentrations [52-54]. Metallothioneins, a family of metal-binding proteins, regulate homeostasis of $\mathrm{Zn}$ and copper, alleviate heavy metal poisoning, and lessen the superoxide stress. Various evidence indicates that metallothionein expression is increased in response to bacterial and viral infections, and it is anticipated that upregulated biosynthesis of human metallothionein might play a significant role in nutritional immunity at the time of active infection [55].

In cell culture studies, inhibition of the replication of various RNA viruses was reported using high $\mathrm{Zn}^{2+}$ concentrations and addition of compounds that stimulate cellular import of $\mathrm{Zn}^{2+}$, such as hinokitiol, pyrrolidine dithiocarbamate, and PT as mentioned above (reviewed in) [5]. Around 10 years ago, an in vitro study demonstrated that the $\mathrm{Zn}$ ionophore PT in combination with $\mathrm{Zn}^{2+}$ is a potent inhibitor of the replication of SARS-CoV1 [51]. In addition, authors also studied the effect of $\mathrm{Zn}$ ions on the RdRp of SARS-CoV-1 and demonstrated that $\mathrm{Zn}^{2+}$ directly inhibited the in vitro activity of RdRp (Fig. 2). More specifically, $\mathrm{Zn}^{2+}$ was found to block the SARS-CoV-1 RdRp elongation step along with reduced template binding. Further strengthening their claim, authors also showed that the $\mathrm{Zn}^{2+}$ mediated RdRp inhibition of SARS-CoV-1 could be reversed through the addition of a $\mathrm{Zn}^{2+}$ chelator [51].

Recently, Finzi (2020) has reported that treatment of four COVID-19 cases with high dose of zinc salts initiated the reduction of disease symptoms within $24 \mathrm{~h}$ after initiation of high dose zinc salt lozenges [56]. As adjuvant therapy, $\mathrm{Zn}$ (in appropriate dose) may provide protection through decreasing lung inflammation, enhancing mucociliary clearance, inhibiting the ventilator-induced lung injury, and immunomodulation in COVID-19 patients [49].

\section{COVID-19: Interventional Clinical Trials of Drugs/Nutritional Supplements with Zn}

As of 4 August 2020, 22 studies were found after searching for $\mathrm{Zn}$ and COVID-19 at the clinical trial website https:// clinicaltrials.gov/ct2/home. However, upon narrowing down the search criteria, 19 studies were clinical trials and the remaining 3 were observational studies (NCT04326725, NCT04407572, NCT04412746). Furthermore, among the remaining 19 studies, one study (NCT04371952 entitled DYNAMIC Study [DoxycYcliNe AMbulatoIre COVID-19]) was based on the fact that doxycycline, a tetracycline antibiotic, is known to chelate $\mathrm{Zn}$ from matrix metalloproteinases, which may help in part to inhibit COVID-19 infection by limiting its ability to replicate in the

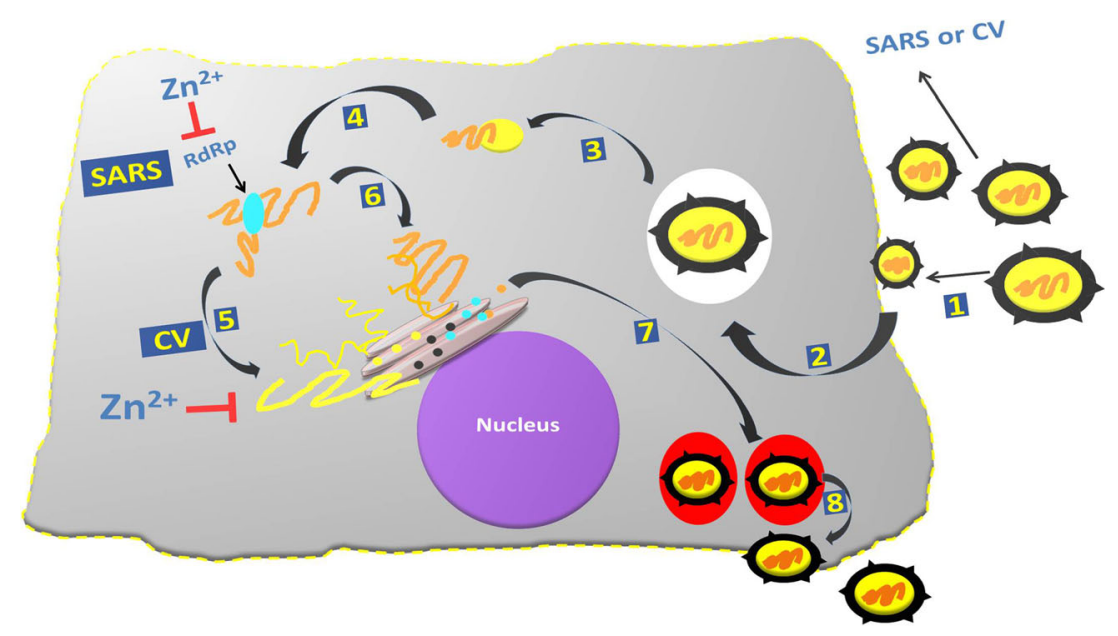

Fig. 2 Schematic representation of different stages of SARS-CoV-1 and coronavirus replication cycle. Viral attachment (1), entry (2), uncoating (3), transcription (4), viral protein translation (5), replication (6), assembly and maturation (7), and finally viral release (8). Data from in vitro studies has demonstrated two mechanisms by which zinc interferes with these viruses' replication cycle steps that include viral genome transcription for SARS-Cov-1 (5), and viral protein translation and polypeptide processing for $\mathrm{CV}$ (6). However, to date, no studies have shown zinc-mediated inhibition of SARS-CoV-1 or CV entry, receptor binding, uncoating, assembly, and/or viral particle release. CV, coronavirus; RdRp, RNA-dependent RNA polymerase; SARS, severe acute respiratory syndrome coronavirus; $\mathrm{Zn}$, zinc 
host. There is no intervention of $\mathrm{Zn}$ supplementation to the patient, so this study was ruled out for present review. Three more studies (NCT04485130, NCT04491994, NCT04485169) also did not use zinc in the experimental arm, so similarly left out from the present article.

Among the remaining 15 studies (Table 1), 4 studies are exclusively using different combinations of dietary supplement including $\mathrm{Zn}$ as an intervention against COVID-19 (NCT04351490, NCT04342728, NCT04323228, NCT04468139 at serial nos. 1, 2, 3, and 4 of Table 1, respectively). None of the four studies is completed yet at the time of writing this review. The NCT04351490 trial is using combination of vitamin $\mathrm{D}_{3}$ with $\mathrm{Zn}$ gluconate with the rationale that these two micronutrients are able to modulate the immune response by reducing the inflammatory storm. Vitamin D, a steroid hormone synthesized from cholesterol, has recently been reported to have anti-fibrotic, anti-inflammatory, and immunomodulatory properties on the basis of various studies done with hepatitis $\mathrm{C}$ virus infection. Vitamin D impedes $\mathrm{T}$ cell proliferation, expression of IFN- $\gamma$, expression of IL-2, and CD8 T lymphocytemediated cytotoxicity [57].

The NCT04342728 trial is primarily studying whether ascorbic acid and $\mathrm{Zn}$ gluconate either alone or in combination can decrease the duration of symptoms in newly diagnosed COVID-19 patients. Ascorbic acid, also known as vitamin C which has potent antioxidant properties, has a very long history ( $>45$ years) in combating or relieving the symptoms of rhinoviruses or common cold [58], and having immune booster properties [59]. Interestingly, various in vitro animal and clinical trials have shown that vitamin C may affect susceptibility to lower respiratory tract infections during the 2003 SARS epidemic [59]. Taking a holistic approach, clinical trial NCT04323228 is using an anti-inflammatory and antioxidant oral nutrition supplement against COVID-19 with rationale that $\mathrm{n}-3$ fatty acids, vitamin $\mathrm{A}$, vitamin $\mathrm{C}$, vitamin $\mathrm{E}$, seleni$\mathrm{um}$, and $\mathrm{Zn}$ in extraordinary doses may modulate the immune system response and improve the cytokine storm-associated COVID-19 (Readers are referred to specialized articles on antioxidant and/or antiviral properties of various nutrients [4]).

Four clinical studies (NCT04377646, NCT04335084, NCT04384458, NCT04446104 at serial nos. 5, 6, 7, and 8 in Table 1, respectively) are preventive studies, which are studying whether hydroxychloroquine and/or vitamin supplements in combination with $\mathrm{Zn}$ are effective as a prophylaxis for asymptomatic healthcare workers/general public. Hydroxychloroquine, derivative of chloroquine having antiinflammatory, immunosuppressive, and anti-autophagy activities, is an anti-malarial drug and anti-rheumatologic agent. Besides, both hydroxychloroquine and chloroquine constrain pH-dependent steps of SARS-CoV-2 replication by increasing $\mathrm{pH}$ in intracellular vesicles [60]. Due to these properties, hydroxychloroquine with $\mathrm{Zn}$ and/or azithromycin has been touted as the medicine and as a prophylactic drug for COVID-19 [61-63]. More importantly, chloroquine and hydroxychloroquine work as $\mathrm{Zn}$ ionophore, thereby increasing the intracellular $\mathrm{Zn}$ concentration [64]. This increase of intracellular $\mathrm{Zn}$ concentration will in turn may help in the inhibition of RdRp of SARS-CoV-2 (reviewed in) [51, 61].

The rest of 5 clinical trials (serial nos. 10-15 of Table 1) are aimed at finding better treatment option for COVID-19 by using various combinations of antiviral drugs/dietary supplements with $\mathrm{Zn}$. The results of these studies are still awaited. The common denominator among the above mentioned trials is the use of $\mathrm{Zn}$ by virtue of its antioxidant, anti-inflammatory, and antiviral properties $[4,5]$. Based on its antioxidant properties, $\mathrm{Zn}$ can protect against age-associated macular degeneration, induced by oxidative stress [65]. In general, these properties are the therapeutic basis of the indication of $Z n$ for the treatment of wounds, burns, and acne vulgaris. In addition, $\mathrm{Zn}$ is very effective in controlling toxic levels of nonceruloplasmin copper in Wilson's disease and other copperrelated diseases [7]. Acting synergistically, various antioxidants and anti-inflammatory nutrients/drugs combined with antiviral drugs may be beneficial at least in alleviating the COVID-19 symptoms or halting the progression to more severe form of COVID-19. For a clear picture, results of these randomized control trials will be eagerly awaited.

\section{Word of Caution: Zn Toxicity}

The recommended dietary allowance (RDA) for $\mathrm{Zn}$ is $11 \mathrm{mg} /$ day for men and $8 \mathrm{mg} /$ day for women [66]. $\mathrm{Zn}$ absorption is influenced by some foods; e.g., animal proteins result in greater $\mathrm{Zn}$ absorption, while phytates reduce its absorption (reviewed in [67]). Zn elimination half-life is in the range of $0.9-1.2 \mathrm{~h}$.

$\mathrm{Zn}$ deficiency is far more widespread in population than $\mathrm{Zn}$ toxicity ( $\mathrm{Zn}$ toxicity is very sporadic and occurs very rarely). In comparison to several other metal ions with similar chemical properties, $\mathrm{Zn}$ is relatively harmless. Having said that, caution should be practiced against indiscriminate selfmedication and chronic use of $\mathrm{Zn}$ supplements without proper medical prescription/monitoring as $\mathrm{Zn}$ toxicity has also been reported in the literature [68-70]. Acute $\mathrm{Zn}$ intoxication is a rare event though exposure to high doses leads to toxic effects. However, it is well established that copper deficiency is associated with taking up large doses of supplemental $\mathrm{Zn}$ over extended periods of time [71-73]. In addition, chronic use of $\mathrm{Zn}$ as supplements [68] or as a medication [74] can block intestinal absorption of copper [75]. The finely tuned and synchronized systemic homeostasis and efficient regulatory mechanisms keep a check on the cytotoxic doses of exogenous $\mathrm{Zn}$. It is the endogenous $\mathrm{Zn}$ that plays a pivotal role in 


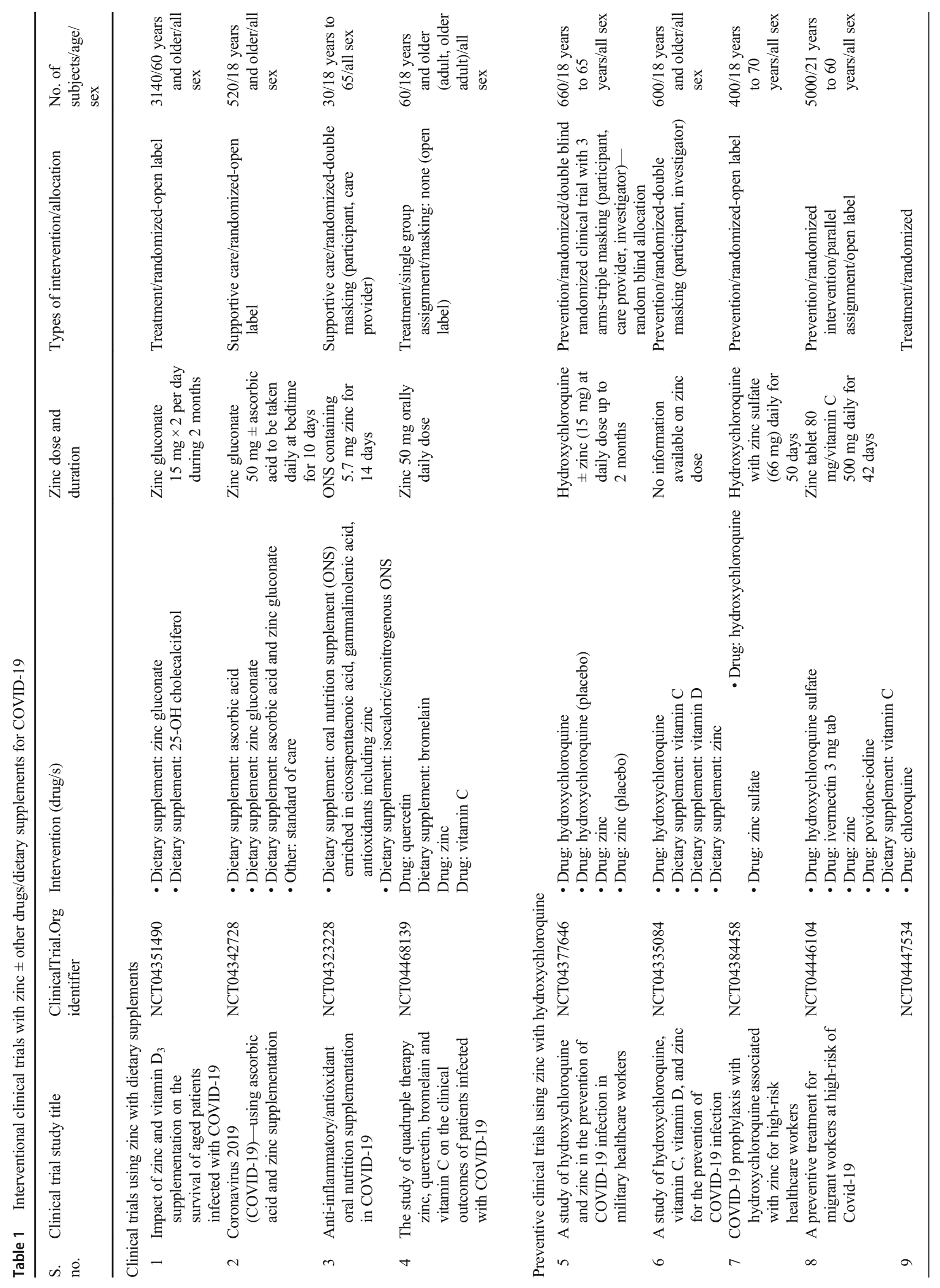




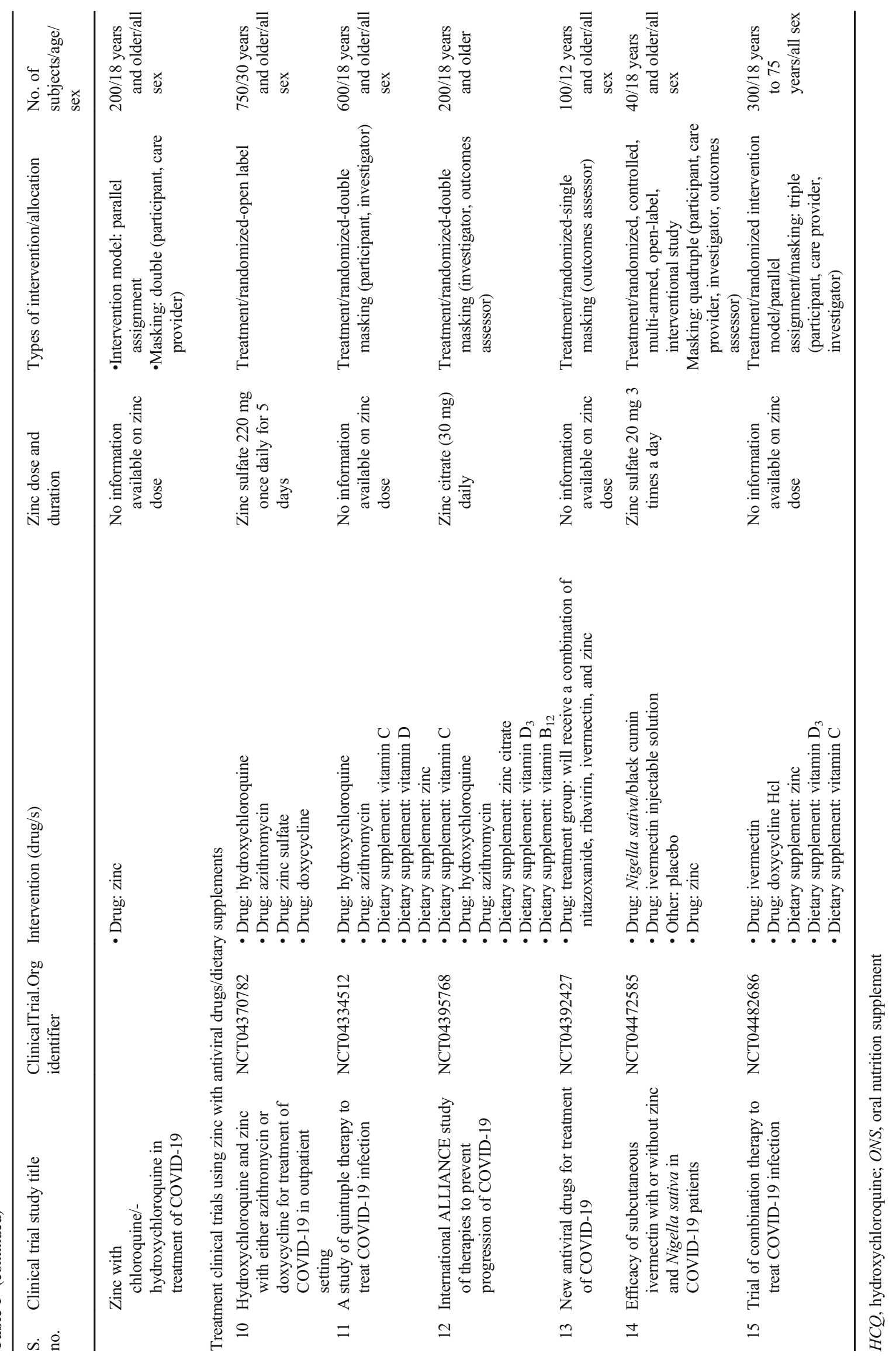


Zn-induced cytotoxic events in single cells. Brain, in particular, is very sensitive to $\mathrm{Zn}$ toxicity.

\section{Zinc as a Two-Edged Sword}

Using $\mathrm{Zn}$ as a supplement or treatment adjuvant is a twoedged sword. Large doses of $\mathrm{Zn}$ (300 mg/day) over 6 weeks can affect the immune response, impairing lymphocyte, and neutrophil function [76]. On this basis, a concern had arisen that long-term $\mathrm{Zn}$ treatment can cause suppression of the immune system. On the similar lines, using excess $\mathrm{Zn}$ supplementation as an antiviral therapy can also do harm to the immune system. Maywald et al. have shown in an in vitro study that excess $\mathrm{Zn}$ supplementation can in fact reduce the expression of IFN- $\gamma$ (a key cytokine for T-helper-1 immune reactions) by reducing interferon regulatory factor 1 expression in regulatory T cells [77]. However, it has been shown for elderly persons that zinc supplementation increased interferon-alpha (IFN- $\alpha$ ) production by leukocytes in vitro as compared to younger subjects [78]. This observation necessitates the need to continuously monitor the levels of $\mathrm{Zn}$ to obtain maximum therapeutic efficacy. Cellular $\mathrm{Zn}$ intake can be improved by ionophores including chloroquine and some of its derivatives such as hydroxychloroquine [64]. Alternatively, natural ionophores of potential use with a good tolerability profile are quercetin and epigallocatechin gallate [79].

\section{Summary and Future Directions}

With no slowing down of COVID-19 pandemic as indicated by 18 million confirmed cases including 0.69 million deaths worldwide as of August 4, 2020 (https://covid19.who.int/), researchers are seeking ways in which to potentially protect people from the SARS-CoV-2 or to alleviate its effects once caught. One such means is $\mathrm{Zn}$ therapy in addition to other antiviral drugs. $\mathrm{Zn}$ is well tolerated and it is best known for its antioxidant, anti-inflammatory, immunomodulatory, and antiviral activities, the latter possibly mediated by its ability to inhibit RNA virus RdRp [51], thus protecting the body's cells and tissues from viral infection, oxidative damage, and dysfunction. Based on the current knowledge of beneficial and harmful effects of Zn (Fig. 1), it can be safely concluded that risk to reward ratio is in favor of $\mathrm{Zn}$ supplementation in COVID-19. However, the clinical and preclinical data on this aspect is very scanty now and results of current clinical trials employing Zn in COVID-19 can somehow shed more light on the efficacy of $\mathrm{Zn}$ against viral infections in vivo. The investigators of the different studies hope to complete the trials in the near future.
Basic and experimental research is still at infancy stage with regard to antiviral mechanisms, clinical benefits, and optimal dose of $\mathrm{Zn}$ supplementation as a therapeutic treatment as well as a preventative measure for viral infections including SARS-CoV-2. Generous funding is the need of hour to rigorously pursue this aspect of basic research and provide conclusive evidence to the clinical trials and assumptions based on current knowledge. Although the findings of these trials will be too late for the many thousands of people currently infected with COVID-19, these studies will offer valued data as to the potential alleviation of symptoms by adjunct $\mathrm{Zn}$ during future viral/COVID-19 outbreaks and provide platform for future research avenues.

Acknowledgments The authors duly acknowledge the WHO, NCBI, and $\mathrm{NIH}$ for providing free online scientific research articles/information/clinical trials pertaining to COVID-19.

Authors' Contributions All authors contributed to the preparation of this review.

\section{Compliance with Ethical Standards}

Competing Interests Dr. Rosanna Squitti is the Chief Scientific Officer of IGEA Pharma N.V.; she has some shares in IGEA Pharma N.V. The other authors declare no competing financial interest.

\section{References}

1. Maret W (2013) Zinc and the zinc proteome. Met Ions Life Sci 12: 479-501. https://doi.org/10.1007/978-94-007-5561-1_14

2. Prasad AS, Miale A Jr, Farid Z, Sandstead HH, Schulert AR (1990) Clinical and experimental. Zinc metabolism in patients with the syndrome of iron deficiency anemia, hepatosplenomegaly, dwarfism, and hypogonadism. 1963. J Lab Clin Med 116(5):737-749

3. Fukada T, Hojyo S, Hara T, Takagishi T (2019) Revisiting the old and learning the new of zinc in immunity. Nat Immunol 20(3):248250. https://doi.org/10.1038/s41590-019-0319-z

4. Gupta S, Read SA, Shackel NA, Hebbard L, George J, Ahlenstiel G (2019) The role of micronutrients in the infection and subsequent response to hepatitis C virus. Cells 8(6):603. Published 2019 Jun 17. https://doi.org/10.3390/cells8060603

5. Read SA, Obeid S, Ahlenstiel C, Ahlenstiel G (2019) The role of zinc in antiviral immunity. Adv Nutr 10(4):696-710. https://doi. org/10.1093/advances/nmz013

6. King JC (2011) Zinc: an essential but elusive nutrient. Am J Clin Nutr 94(2):679S-684S. https://doi.org/10.3945/ajcn.110.005744

7. Sensi SL, Granzotto A, Siotto M, Squitti R (2018) Copper and zinc dysregulation in Alzheimer's disease. Trends Pharmacol Sci 39(12):1049-1063. https://doi.org/10.1016/j.tips.2018.10.001

8. Sensi SL, Paoletti P, Bush AI, Sekler I (2009) Zinc in the physiology and pathology of the CNS. Nat Rev Neurosci 10(11):780-791. https://doi.org/10.1038/nrn2734

9. Fukada T, Yamasaki S, Nishida K, Murakami M, Hirano T (2011) Zinc homeostasis and signaling in health and diseases: zinc signaling. J Biol Inorg Chem 16(7):1123-1134. https://doi.org/10.1007/ s00775-011-0797-4

10. Hara T, Takeda TA, Takagishi T, Fukue K, Kambe T, Fukada T (2017) Physiological roles of zinc transporters: molecular and 
genetic importance in zinc homeostasis. J Physiol Sci 67(2):283301. https://doi.org/10.1007/s12576-017-0521-4

11. Hojyo S, Fukada T (2016) Zinc transporters and signaling in physiology and pathogenesis. Arch Biochem Biophys 611:43-50. https://doi.org/10.1016/j.abb.2016.06.020

12. Mezzaroba L, Alfieri DF, Colado Simão AN, Vissoci Reiche EM (2019) The role of zinc, copper, manganese and iron in neurodegenerative diseases. Neurotoxicology 74:230-241. https://doi.org/ 10.1016/j.neuro.2019.07.007

13. Sanna A, Firinu D, Zavattari P, Valera P (2018) Zinc status and autoimmunity: a systematic review and meta-analysis. Nutrients. 10(1):68. https://doi.org/10.3390/nu10010068

14. Subramanian Vignesh K, Deepe GS Jr (2016) Immunological orchestration of zinc homeostasis: the battle between host mechanisms and pathogen defenses. Arch Biochem Biophys 611:66-78. https://doi.org/10.1016/j.abb.2016.02.020

15. Vasto S, Mocchegiani E, Candore G, Listì F, Colonna-Romano G, Lio D, Malavolta M, Giacconi R, Cipriano C, Caruso C (2006) Inflammation, genes and zinc in ageing and agerelated diseases. Biogerontology. 7(5-6):315-327. https://doi.org/10.1007/s10522006-9046-6

16. Gumulec J, Masarik M, Krizkova S, Adam V, Hubalek J, Hrabeta J, Eckschlager T, Stiborova M, Kizek R (2011) Insight to physiology and pathology of zinc(II) ions and their actions in breast and prostate carcinoma. Curr Med Chem 18(33):5041-5051. https://doi.org/ $10.2174 / 092986711797636126$

17. Rahman MT, Idid SZ (2020) Can Zn be a critical element in COVID-19 treatment? Biol Trace Elem Res. https://doi.org/10. 1007/s12011-020-02194-9

18. Nile SH, Nile A, Qiu J, Li L, Jia X, Kai G (2020) COVID-19: pathogenesis, cytokine storm and therapeutic potential of interferons. Cytokine Growth Factor Rev 53:66-70. https://doi.org/10. 1016/j.cytogfr.2020.05.002

19. Ye Q, Wang B, Mao J (2020) The pathogenesis and treatment of the 'cytokine storm' in COVID-19. J Inf Secur 80(6):607-613. https:// doi.org/10.1016/j.jinf.2020.03.037

20. Blanco-Melo D, Nilsson-Payant BE, Liu WC, Uhl S, Hoagland D, Møller R, Jordan TX, Oishi K, Panis M, Sachs D, Wang TT, Schwartz RE, Lim JK, Albrecht RA, ten Oever BR (2020) Imbalanced host response to SARS-CoV-2 drives development of COVID-19. Cell 181(5):1036-1045.e9. https://doi.org/10.1016/j. cell.2020.04.026

21. Kopecky-Bromberg SA, Martínez-Sobrido L, Frieman M, Baric RA, Palese P (2007) Severe acute respiratory syndrome coronavirus open reading frame (ORF) $3 \mathrm{~b}$, ORF 6 , and nucleocapsid proteins function as interferon antagonists. J Virol 81(2):548-557. https:// doi.org/10.1128/JVI.01782-06

22. Okba NMA, Müller MA, Li W, Wang C, GeurtsvanKessel CH, Corman VM, Lamers MM, Sikkema RS, de Bruin E, Chandler FD, Yazdanpanah Y, le Hingrat Q, Descamps D, Houhou-Fidouh N, Reusken CBEM, Bosch BJ, Drosten C, Koopmans MPG, Haagmans BL (2020) Severe acute respiratory syndrome coronavirus 2-specific antibody responses in coronavirus disease patients. Emerg Infect Dis 26(7):1478-1488. https://doi.org/10.3201/ eid2607.200841

23. Lee N, Chan PK, Ip M, Wong E, Ho J, Ho C, Cockram CS, Hui DS (2006) Anti-SARS-CoV IgG response in relation to disease severity of severe acute respiratory syndrome. J Clin Virol 35(2):179-184. https://doi.org/10.1016/j.jcv.2005.07.005

24. Lou B, Li T-D, Zheng S-F, Su YY, Li ZY, Liu W, Yu F, Ge SX, Zou QD, Yuan Q, Lin S, Hong CM, Yao XY, Zhang XJ, Wu DH, Zhou GL, Hou WH, Li TT, Zhang YL, Zhang SY, Fan J, Zhang J, Xia NS, Chen Y (2020) Serology characteristics of SARS-CoV-2 infection since exposure and post symptom onset. Eur Respir J 56: 2000763 in press. https://doi.org/10.1183/13993003.00763-2020
25. Zheng S, Fan J, Yu F, Feng B, Lou B, Zou Q, Xie G, Lin S, Wang R, Yang X, Chen W, Wang Q, Zhang D, Liu Y, Gong R, Ma Z, Lu S, Xiao Y, Gu Y, Zhang J, Yao H, Xu K, Lu X, Wei G, Zhou J, Fang Q, Cai H, Qiu Y, Sheng J, Chen Y, Liang T (2020) Viral load dynamics and disease severity in patients infected with SARSCoV-2 in Zhejiang province, China, January-March 2020: retrospective cohort study. BMJ. 369:m1443. https://doi.org/10.1136/ bmj.m1443

26. Brudno JN, Kochenderfer JN (2019) Recent advances in CAR Tcell toxicity: mechanisms, manifestations and management. Blood Rev 34:45-55. https://doi.org/10.1016/j.blre.2018.11.002

27. Li J, Piskol R, Ybarra R, Chen YJ, Li J, Slaga D, Hristopoulos M, Clark R, Modrusan Z, Totpal K, Junttila MR, Junttila TT (2019) CD3 bispecific antibody-induced cytokine release is dispensable for cytotoxic T cell activity. Sci Transl Med 11(508):eaax8861. https://doi.org/10.1126/scitranslmed.aax8861

28. Sterner RM, Sakemura R, Cox MJ, Yang N, Khadka RH, Forsman CL, Hansen MJ, Jin F, Ayasoufi K, Hefazi M, Schick KJ, Walters DK, Ahmed O, Chappell D, Sahmoud T, Durrant C, Nevala WK, Patnaik MM, Pease LR, Hedin KE, Kay NE, Johnson AJ, Kenderian SS (2019) GM-CSF inhibition reduces cytokine release syndrome and neuroinflammation but enhances CAR-T cell function in xenografts. Blood. 133(7):697-709. https://doi.org/10.1182/ blood-2018-10-881722

29. Seillet $\mathrm{C}$, Laffont $\mathrm{S}$, Trémollières $\mathrm{F}$, Rouquié $\mathrm{N}$, Ribot $\mathrm{C}$, Arnal JF, Douin-Echinard V, Gourdy P, Guéry JC (2012) The TLR-mediated response of plasmacytoid dendritic cells is positively regulated by estradiol in vivo through cell-intrinsic estrogen receptor $\alpha$ signaling. Blood. 119(2):454-464. https://doi.org/10.1182/blood-201108-371831

30. Loutfy MR, Blatt LM, Siminovitch KA, Ward S, Wolff B, Lho H, Pham DH, Deif H, LaMere EA, Chang M, Kain KC, Farcas GA, Ferguson P, Latchford M, Levy G, Dennis JW, Lai EK, Fish EN (2003) Interferon alfacon-1 plus corticosteroids in severe acute respiratory syndrome: a preliminary study. JAMA. 290(24):32223228. https://doi.org/10.1001/jama.290.24.3222

31. Channappanavar R, Fehr AR, Vijay R, Mack M, Zhao J, Meyerholz DK, Perlman S (2016) Dysregulated type I interferon and inflammatory monocyte-macrophage responses cause lethal pneumonia in SARS-CoV-infected mice. Version 2. Cell Host Microbe 19(2): 181-193. https://doi.org/10.1016/j.chom.2016.01.007

32. Nomellini V, Gomez CR, Kovacs EJ (2008) Aging and impairment of innate immunity. Contrib Microbiol 15:188-205. https://doi.org/ $10.1159 / 000136358$

33. Thomas R, Wang W, Su DM (2020) Contributions of age-related thymic involution to immunosenescence and inflammaging. Immun Ageing 17:2. https://doi.org/10.1186/s12979-020-0173-8

34. Prasad AS (2009) Zinc: role in immunity, oxidative stress and chronic inflammation. Curr Opin Clin Nutr Metab Care 12(6): 646-652. https://doi.org/10.1097/MCO.0b013e3283312956

35. Shankar AH, Prasad AS (1998) Zinc and immune function: the biological basis of altered resistance to infection. Am J Clin Nutr 68(2 Suppl):447S-463S. https://doi.org/10.1093/ajen/68.2.447S

36. Fraker PJ, DePasquale-Jardieu P, Zwickl CM, Luecke RW (1978) Regeneration of T-cell helper function in zinc-deficient adult mice. Proc Natl Acad Sci U S A 75(11):5660-5664. https://doi.org/10. 1073/pnas.75.11.5660

37. Frost P, Rabbani P, Smith J, Prasad A (1981) Cell-mediated cytotoxicity and tumor growth in zincdeficient mice. Proc Soc Exp Biol Med 167(3):333-337. https://doi.org/10.3181/00379727-16741174

38. Bonaventura P, Benedetti G, Albarède F, Miossec P (2015) Zinc and its role in immunity and inflammation. Autoimmun Rev 14(4): 277-285. https://doi.org/10.1016/j.autrev.2014.11.008 
39. Berg K, Bolt G, Andersen H, Owen TC (2001) Zinc potentiates the antiviral action of human IFNalpha tenfold. J Interf Cytokine Res 21(7):471-474. https://doi.org/10.1089/10799900152434330

40. Qin C, Zhou L, Hu Z, Zhang S, Yang S, Tao Y, Xie C, Ma K, Shang K, Wang W, Tian DS (2020) Dysregulation of immune response in patients with COVID-19 in Wuhan, China. Clin Infect Dis:ciaa248. https://doi.org/10.1093/cid/ciaa248

41. Morgan CI, Ledford JR, Zhou P, Page K (2011) Zinc supplementation alters airway inflammation and airway hyperresponsiveness to a common allergen. J Inflamm (Lond) 8:36. https://doi.org/10. $1186 / 1476-9255-8-36$

42. Zang R, Lian H, Zhong X, Yang Q, Shu HB (2020) ZCCHC3 modulates TLR3-mediated signaling by promoting recruitment of TRIF to TLR3. J Mol Cell Biol 12(4):251-262. https://doi.org/10. 1093/jmcb/mjaa004

43. Wong CP, Rinaldi NA, Ho E (2015) Zinc deficiency enhanced inflammatory response by increasing immune cell activation and inducing IL6 promoter demethylation. Mol Nutr Food Res 59(5): 991-999

44. Beck FW, Prasad AS, Kaplan J, Fitzgerald JT, Brewer GJ (1997) Changes in cytokine production and $\mathrm{T}$ cell subpopulations in experimentally induced zinc-deficient humans. Am J Phys 272(6 Pt 1):E1002-E1007. https://doi.org/10.1152/ajpendo.1997.272.6. E1002

45. Yasuda H, Tsutsui $\mathrm{T}$ (2016) Infants and elderlies are susceptible to zinc deficiency. Sci Rep 6:21850. https://doi.org/10.1038/ srep2 1850

46. Dinsmore W, Callender ME, McMaster D, Todd SJ, Love AH (1985) Zinc absorption in alcoholics using zinc-65. Digestion 32(4):238-242. https://doi.org/10.1159/000199243

47. Manari AP, Preedy VR, Peters TJ (2003) Nutritional intake of hazardous drinkers and dependent alcoholics in the UK. Addict Biol 8(2):201-210. https://doi.org/10.1080/1355621031000117437

48. Mills PR, Fell GS, Bessent RG, Nelson LM, Russell RI (1983) A study of zinc metabolism in alcoholic cirrhosis. Clin Sci (Lond) 64(5):527-535. https://doi.org/10.1042/cs0640527

49. Skalny AV, Rink L, Ajsuvakova OP, Aschner M, Gritsenko VA, Alekseenko SI, Svistunov AA, Petrakis D, Spandidos DA, Aaseth J, Tsatsakis A, Tinkov AA (2020) Zinc and respiratory tract infections: perspectives for COVID19 (Review). Int J Mol Med 46(1): 17-26. https://doi.org/10.3892/ijmm.2020.4575

50. Prasad AS (2008) Clinical, immunological, anti-inflammatory and antioxidant roles of zinc. Exp Gerontol 43(5):370-377. https://doi. org/10.1016/j.exger.2007.10.013

51. te Velthuis AJ, van den Worm SH, Sims AC, Baric RS, Snijder EJ, van Hemert MJ (2010) $\mathrm{Zn}(2+)$ inhibits coronavirus and arterivirus RNA polymerase activity in vitro and zinc ionophores block the replication of these viruses in cell culture. PLoS Pathog 6(11): e1001176

52. Alirezaei M, Nairn AC, Glowinski J, Prémont J, Marin P (1999) Zinc inhibits protein synthesis in neurons. Potential role of phosphorylation of translation initiation factor-2alpha. J Biol Chem 274(45):32433-32438. https://doi.org/10.1074/jbc.274.45.32433

53. Frederickson CJ, Koh JY, Bush AI (2005) The neurobiology of zinc in health and disease. Nat Rev Neurosci 6(6):449-462. https://doi.org/10.1038/nrn1671

54. Lazarczyk M, Favre M (2008) Role of Zn2+ ions in host-virus interactions. J Virol 82(23):11486-11494. https://doi.org/10.1128/ JVI.01314-08

55. Rahman MT, Karim MM (2018) Metallothionein: a potential link in the regulation of zinc in nutritional immunity. Biol Trace Elem Res 182(1):1-13. https://doi.org/10.1007/s12011-017-1061-8

56. Finzi E (2020) Treatment of SARS-CoV-2 with high dose oral zinc salts: a report on four patients. Int J Infect Dis 99:307-309. https:// doi.org/10.1016/j.ijid.2020.06.006
57. Jin CN, Chen JD, Sheng JF (2018) Vitamin D deficiency in hepatitis $\mathrm{C}$ virus infection: what is old? what is new? Eur J Gastroenterol Hepatol 30(7):741-746. https://doi.org/10.1097/MEG. 0000000000001134

58. Bucher A, White N (2016) Vitamin C in the prevention and treatment of the common cold. Am J Lifestyle Med 10(3):181-183. https://doi.org/10.1177/1559827616629092

59. Hemilã H (2003) Vitamin C and SARS coronavirus. J Antimicrob Chemother 52(6):1049-1050. https://doi.org/10.1093/jac/dkh002

60. Schrezenmeier E, DÃrner T (2020) Mechanisms of action of hydroxychloroquine and chloroquine: implications for rheumatology. Nat Rev Rheumatol 16(3):155-166. https://doi.org/10.1038/ s41584-020-0372-x

61. Derwand R, Scholz M (2020) Does zinc supplementation enhance the clinical efficacy of chloroquine/hydroxychloroquine to win today's battle against COVID-19? Med Hypotheses 142:109815. https://doi.org/10.1016/j.mehy.2020.109815

62. Pastick KA, Okafor EC, Wang F, Lofgren SM, Skipper CP, Nicol MR, Pullen MF, Rajasingham R, McDonald EG, Lee TC, Schwartz IS, Kelly LE, Lother SA, Mitjà O, Letang E, Abassi M, Boulware DR (2020) Review: hydroxychloroquine and chloroquine for treatment of SARS-CoV-2 (COVID-19). Version 2. Open Forum Infect Dis 7(4):ofaa130. https://doi.org/10.1093/ofid/ofaa130

63. Touret F, de Lamballerie X (2020) Of chloroquine and COVID-19. Antivir Res 177:104762. https://doi.org/10.1016/j.antiviral.2020. 104762

64. Xue J, Moyer A, Peng B, Wu J, Hannafon BN, Ding WQ (2014) Chloroquine is a zinc ionophore. PLoS One 9(10):e109180. https:// doi.org/10.1371/journal.pone.0109180

65. Micera A, Bruno L, Cacciamani A, Rongioletti M, Squitti R (2019) Alzheimer's disease and retinal degeneration: a glimpse at essential trace metals in ocular fluids and tissues. Curr Alzheimer Res $16(12): 1073-1083$. https://doi.org/10.2174/ 1567205016666191023114015

66. Trumbo P, Yates AA, Schlicker S, Poos M (2001) Dietary reference intakes: vitamin $\mathrm{A}$, vitamin $\mathrm{K}$, arsenic, boron, chromium, copper, iodine, iron, manganese, molybdenum, nickel, silicon, vanadium, and zinc. J Am Diet Assoc 101(3):294-301. https://doi.org/10. 1016/S0002-8223(01)00078-5

67. Tuerk MJ, Fazel N (2009) Zinc deficiency. Curr Opin Gastroenterol 25(2):136-143. https://doi.org/10.1097/MOG.0b013e328321b395

68. Maret W, Sandstead HH (2006) Zinc requirements and the risks and benefits of zinc supplementation. J Trace Elem Med Biol 20(1):318. https://doi.org/10.1016/j.jtemb.2006.01.006

69. Fosmire GJ (1990) Zinc toxicity. Am J Clin Nutr 51(2):225-227. https://doi.org/10.1093/ajen/51.2.225

70. Plum LM, Rink L, Haase H (2010) The essential toxin: impact of zinc on human health. Int J Environ Res Public Health 7(4):13421365. https://doi.org/10.3390/ijerph7041342

71. Magee AC, Matrone G (1960) Studies on growth, copper metabolism of rats fed high levels of zinc. J Nutr 72(2):233-242. https:// doi.org/10.1093/jn/72.2.233

72. Ogiso T, Moriyama K, Sasaki S, Ishimura Y, Minato A (1974) Inhibitory effect of high dietary zinc on copper absorption in rats. Chem Pharm Bull (Tokyo) 22(1):55-60. https://doi.org/10.1248/ cpb.22.55

73. Van Campen DR (1969) Copper interference with the intestinal absorption of zinc-65 by rats. J Nutr 97(1):104-108. https://doi. org/10.1093/jn/97.1.104

74. Gupta P, Choksi M, Goel A, Zachariah U, Sajith KG, Ramachandran J, Chandy G, Kurian G, Rebekah G, Eapen CE (2018) Maintenance zinc therapy after initial penicillamine chelation to treat symptomatic hepatic Wilson's disease in resource constrained setting. Indian J Gastroenterol 37(1):31-38. https:// doi.org/10.1007/s12664-018-0829-x 
75. Członkowska A, Litwin T, Dusek P, Ferenci P, Lutsenko S, Medici V, Rybakowski JK, Weiss KH, Schilsky ML (2018) Wilson disease. Nat Rev Dis Primers 4(1):21. https://doi.org/10.1038/s41572018-0018-3

76. Chandra RK (1984) Excessive intake of zinc impairs immune responses. JAMA 252(11):1443-1446

77. Maywald M, Rink L (2017) Zinc supplementation induces CD4+ CD25+Foxp3+ antigenspecific regulatory $\mathrm{T}$ cells and suppresses IFN- $\gamma$ production by upregulation of Foxp3 and KLF-10 and downregulation of IRF-1. Eur J Nutr 6(5):1859-1869. https://doi. org/10.1007/s00394-016-1228-7

78. Cakman I, Kirchner H, Rink L (1997) Zinc supplementation reconstitutes the production of interferon-alpha by leukocytes from elderly persons. J Interf Cytokine Res 17(8):469-472. https://doi. org/10.1089/jir.1997.17.469

79. Dabbagh-Bazarbachi H, Clergeaud G, Quesada IM, Ortiz M, O'Sullivan CK, Fernández-Larrea JB (2014) Zinc ionophore activity of quercetin and epigallocatechin-gallate: from Hepa 1-6 cells to a liposome model. J Agric Food Chem 62(32):8085-8093. https:// doi.org/10.1021/jf5014633

Publisher's Note Springer Nature remains neutral with regard to jurisdictional claims in published maps and institutional affiliations. 